Подальші дослідження із даної проблематики плануємо спрямовувати на системний аналіз концептуальних ідей, сутності та складових методики реалізації STEAM-підходу до навчання й вивчення математики з метою розвитку креативної компетенції здобувачів освіти та полікультурної компетентності вчителів математики. Важливим подальшим напрямом $є$ також дослідження впливу STEAM-підходу на підвищення рівня професійної компетентності учителів математики, реалізацію їхніх потреб щодо саморозвитку з метою покращення конкурентоздатності в умовах багатокультурного глобалізованого світу.

\section{СПИСОК ВИКОРИСТАНОЇ ЛІТЕРАТУРИ}

1. Концепція STEM-освіти в Україні : проєкт URL: http://mk-kor.at.ua/STEM/STEM_2017.pdf (дата звернення: 21.07.2020).

2. Про схвалення Концепції розвитку природничо-математичної освіти (STEM-освіти) : розпорядження Кабінету Міністрів України від 5 серпня 2020 p. №960-p. URL: https://zakon.rada.gov.ua/ laws/show/960-2020-\%D1\%80\#Text (дата звернення: 14.09.2020).

3. Про оголошення 2020/2021 навчального року Роком математичної освіти в Україні : Указ Президента України №31/2020. URL: https://www.president. gov.ua/documents/312020-32165 (дата звернення: 24.07.2020).

УДК 37.018.43:378

DOI: 10.37026/2520-6427-2020-103-3-66-65
4. What is STEAM Education? URL: https:// educationcloset.com/what-is-steam-education-in-k-12schools/ (дата звернення: 22.07.2020).

5. How STEAM education develops 21st century skills. URL: https://www.studyinternational.com/news/ steam-education/ (дата звернення: 22.07.2020).

6. Expanding the Math Classroom with STEM or STEAM. URL: https://blog.savvas.com/expanding-themath-classroom-with-stem-or-steam/ (дата звернення: 25.07.2020).

7. Susan Riley. Особиста сторінка Сьюзен Райлі в міжнародній професійній спільноті Linkedin. URL: https://www.linkedin.com/in/susan-riley-78199140. (дата звернення: 23.07.2020).

8. Georgette Yakman. Developing STEAM Education to Improve Student's Innovative Ability. URL: https://steamedu.com/developing-steam-education-toimprove-students-innovative-ability/ (дата звернення: 23.07.2020)

9. All Education School. Міжнародна мережева педагогічна спільнота. URL: https://www. alleducationschools.com/resources/steam-education/ (дата звернення: 24.07.2020).

10. PISA 2018 Results.Combined Executive Summaries. URL: https://www.oecd.org/pisa/Combined Executive_Summaries_PISA_2018.pdf (дата звернення: 14.09.2020).

Дата надходження до редакиї: 14.09.2020 p.

Наталія РИСИНЕЦЬ,

завідувач економіко-правового відділення

Коледжу економіки і права

Вінницького кооперативного інституту, м. Вінниця

\title{
ЗАСТОСУВАННЯ ІННОВАЦІЙНИХ ТЕХНОЛОГІЙ 3 МЕТОЮ ФОРМУВАННЯ ГОТОВНОСТІ ФАХІВЦІВ ІЗ МІЖНАРОДНОГО ПРАВА ДО ПРОФЕСІЙНОЇ ДІЯЛЬНОСТІ
}

\footnotetext{
У статті означено та проаналізовано проблему застосування інновачійних технологій, зокрема технологій презентаиій, з метою формування готовності фахівиів із міжнародного права до професійної діяльності. Розкрито методичні аспекти використання сучасних технологій презентацій під час навчання фахівиів із міжнародного права: изілі та головні елементи, вибір формату, конструювання тем, організаційна підготовка, очінювання результатів та інше. Основну увагу приділено висвітленню особливостей
}

використання скрайбінгу та мнемоніки на лекційних заняттях, впливу технологій презентаиій на мотивацію, зацікавленість студентів та якісну успішність. Аналіз педагогічної та правової літератури, а також власний педагогічний досвід свідчать, щзо проблема впровадження технологій презентацій в освітній прочес повністю не вивчена та потребує подальших досліджень. Особливо гостро ияе відчувається в умовах переходу системи освіти на дистаниійне навчання, зокрема у зв'язку з пандемією коронавірусу. 
Наразі освітній процес уже неможливо уявити без застосування інноваційних інформаційно-комунікаціииних технологій, адже сучасні студенти втратили зацікавленість до традиційних методів навчання, які не дають змоги сформувати готовність фахівиів із міжнародного права до практичноі діяльності.

У прочесі аналізу науково-методичних джерел із теми дослідження було виявлено низку проблем, щзо потребують розв'язання, як-от: недостатня комп'ютерна компетентність у викладачів, щзоб швидко адаптуватись до сучасних вимог дистанційного навчанняз використаннямтехнологійпрезентаиій; відсутність якісних підручників та навчальних посібників, до яких наведені методичними вказівки щодо використання сучасних технологій презентаиій при вивчені юридичних дисциплін; відсутність нових навчальних програм підготовки майбутніх фахівиів із міжнародного права, щзо відповідають вимогам часу.

Ключові слова: інноваційні технології, фахівиі з міжнародного права, скрайбінг-презентація, технології презентацій, мнемоніка.

В статье проанализирована проблема применения инновачионных технологий, в частности технологий презентаций, для формирования готовности специалистов по международному праву для профессиональной деятельности. Раскрываются методические аспекты использования современных технологий презентациий в процессе обучения специиалистов по международному праву: иели и главнье элементы, выбор формата, конструирование тем, организационная подготовка, оценка результатов и прочее. Основное внимание уделено особенностям использования скрайбинга и мнемоники во время лекционных занятий, влиянию технологий презентаций на мотиваиию и заинтересованность студентов и качественную успеваемость. Анализ педагогической и правовой литературы, а также собственный педагогический опыт показывают, что проблема внедрения технологий презентаичй в образовательный процесс полностью не изучена и требует дальнейших исследований. Особенно остро это ощущается в условиях перехода системы образования на дистанционное обучение, в том числе в связи с пандемией коронавируса. Сейчас учебно-воспитательньй проиесс уже невозможно представить без применения инновационных информационно-коммуникационных технологий, ведь современные студенты потеряли интерес к традииионным методам обучения, которые не позволяют сформировать готовность специалистов по международному праву в практической деятельности.

В проиессе анализа научно-методических источников по теме исследования был выявлен ряд проблем, требуюших решения: недостаточная компьютерная компетентность преподавателей, чтобы быстро адаптироваться $\kappa$ современнылм требованиям дистаничонного обучения с использованием технологий презентаций; отсутствие качественных учебников и учебных пособий, в которых приведены методические указания по использованию современных технологий презентащий при изучении юридических дисииплин; отсутствие новых учебных программ подготовки будущих специалистов по международному праву, отвечающих требованиям времени.

Ключевые слова: инновачионные технологии, спеициалисты по международному праву, скрайбинг-презентация, технологии презентаций, мнемоника.

The article identifies and analyzes the problem of using innovative technologies, in particular presentation technologies, to form the readiness of specialists in international law for professional activity. The methodological aspects of using modern presentation technologies in the process of training specialists in international law are revealed: goals and main elements, choice of format, construction of topics, organizational training, evaluation of results and more. The main attention is paid to the peculiarities of the use of scribing and mnemonics during lectures, the impact of presentation technologies on the motivation and interest of students and quality performance. The analysis of pedagogical and legal literature, as well as our own pedagogical experience show that the problem of introducing presentation technologies into the educational process has not been fully studied and needs further research. This is particularly acute in the context of the transition of the education system to distance learning, in particular in connection with the coronavirus pandemic. At present, the educational process can no longer be imagined without the use of innovative information and communication technologies, because modern students have lost interest in traditional teaching methods, which do not allow to form the readiness of specialists in international law to practice.

In addition, the analysis of scientific and methodological sources on the research topic revealed a number of problems that need to be addressed: lack of computer competence of teachers to quickly adapt to modern requirements of distance learning using presentation technologies; lack of quality textbooks and manuals, which provide guidelines for the use of modern presentation technologies in the study of legal disciplines; lack of new training programs for future specialists in international law that meet the requirements of the time.

Key words: innovative technologies, specialists in international law, scribing presentation, presentation technologies, mnemonics.

Постановка проблеми. На сучасному етапі розвитку суспільства міжнародні відносини, а 3 ними й розуміння міжнародного права, зазнали суттєвих змін. Тому положення міжнародного права потребують серйозного перегляду та доопрацювання. Курс на євроінтеграцію та розбудова правової держави в Україні вимагають не лише адаптації національного законодавства до міжнародного, але й усебічного вивчення норм міжнародного права, аналізу міжнародного законодавства та, що найголовніше, підготовки компетентних фахівців-юристів.

Необхідність поліпшення та доопрацювання технологій дистанційного навчання в сучасних реаліях вимагає швидкої адаптації до вимог часу, особливо гостро це відчувається у зв'язку з пандемією коронавірусу 
та запровадженням нових програм підготовки фахівців із міжнародного права. Компетентнісний підхід, який використовується в закладах вищої освіти, має на меті сформувати у студентів-правників необхідні для ефективної практичної діяльності знання, уміння, навички та компетентності.

Наразі студентів уже не можна зацікавити монотонним читанням матеріалу із застарілих підручників. Отже, викладачі дедалі частіше змушені використовувати інноваційні технології навчання, зокрема скрайбінг і мнемоніку.

Аналіз наукових досліджень та публікацій. Проблеми застосування технологій скрайбінгу та мнемоніки у процесі навчання активно досліджуються як зарубіжними, так і вітчизняними науковцями. Так, О. Черепаха, Н. Гаджул, М. Горай розглядали впровадження мнемоніки під час підготовки студентів медичних спеціальностей; О. Ярмощук, В. Василюк описали необхідність застосування мнемоніки для студентів спеціальності «Фізичне виховання». У контексті вивчення інтерактивних технологій навчання доцільність застосування скрайбінгу та мнемоніки проаналізували Н. Сидорчук, Н. Бараненкова та Л. Светенок.

Незважаючи на інтерес науковців до використання технологій скрайбінгу і мнемоніки та їхню ефективність у процесі підготовки студентів, проблема вивчення методичних аспектів застосування цих технологій у навчанні фахівців із міжнародного права окремо не досліджувалася, що й зумовлює актуальність нашої статті.

Метою статті $\epsilon$ аналіз проблеми застосування інноваційних технологій, зокрема технологій презентацій, для формування готовності фахівців із міжнародного права до професійної діяльності.
Виклад основного матеріалу. Скрайбінг - це візуальні зображення, перетворення слів і думок на візуальні образи. У закладах вищої освіти скрайбінг-презентації почали використовувати відносно нещодавно. Одним із перших скрайбінг як інтерактивний продукт використав американський викладач П. Богуш. Застосуванням скрайбінгу він спростував давно відоме освітнє гасло «читай параграф із підручника - відповідай на запитання» та довів ефективність використання скрайб-презентації у навчальному процесі [5].

Мнемоніка (від грец. тпети - пам'ять) - сукупність прийомів, які дають змогу швидше та якісніше запам'ятовувати інформацію. Мнемоніка грунтується на принципах створення асоціативних зв' язків і зміні типу інформації й так чи інакше пов'язана зі створенням асоціативних зв'язків, адже найкраще ми пам'ятаємо те, що нам було вже відомо раніше, - потрібно лише закріпити відому інформацію якісним асоціативним зв'язком. Зміна типу інформації - це щось на зразок перетворення PDF-файлів y DOC. Наприклад, замість того, щоб запам'ятовувати числа, ми запам'ятовуємо слова або зображення замість слів. Основне завдання полягає в тому, щоб «зашифрувати» інформацію для полегшення запам'ятовування та відтворення.

Автор книги «Суперпам'ять» Т. Б'юзен висловив один із принципів мнемоніки: «Якщо ти хочеш запам'ятати щось нове, тобі потрібно всього лише знайти асоціативний зв'язок із чимось уже відомим». Отже, використання візуальних образів, до яких формуються асоціативні прив'язки, сприяють кращому запам'ятовуванню лекційного матеріалу. Таким чином, підвищується і якість навчання. Для прикладу, на рuсунку 1 наведено асоціативний малюнок до лекційного заняття з теми «Вступ до міжнародного права».

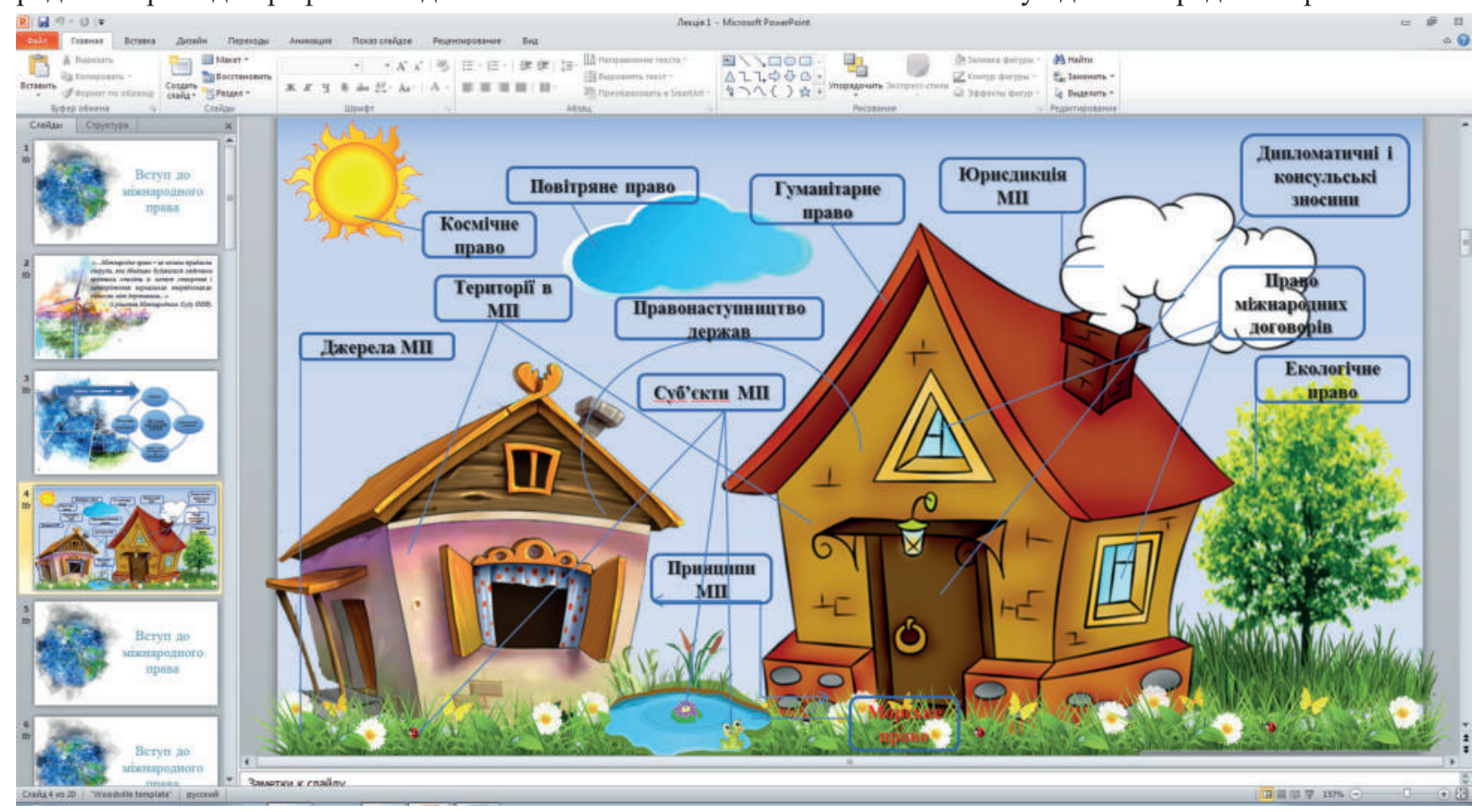

Рис. 1. Скрайбінг-презентація до лекиії «Вступ до міжнародного права» з елементами мнемоніки

На основі скрайбінг-презентації формуємо асоціативні зв'язки, наведені на рисунку 1 . На думку відомого англійського юриста Дж. О’Браєна, основними галузями сучасного міжнародного права є: джерела міжнародного права, суб'єкти міжнародного права, визнання держав і урядів, територія, юрисдикція, суверенний імунітет, дипломатичні та консульські зносини, право договорів, право міжнародної відповідальності, 
морське право, повітряне та космічне право, міжнародне гуманітарне право, міжнародне екологічне право, правонаступництво держав, міжнародне економічне право, мирне розв'язання суперечок між державами, міжнародне право та застосування державами сили, міжнародні організації, право збройних конфліктів. Цей перелік, звісно, не є повним або вичерпним, однак він створює досить непогане уявлення із сучасної системи міжнародних публічно-правових відносин [6].

Розглянемо основні галузі міжнародного права за допомогою візуалізації, що наведена. Уявимо, що все міжнародне право - це наш рисунок 1. Далі використовуємо принципи мнемоніки та формуємо візуальні паралелі, що допоможуть краще запам'ятовувати матеріал. Розглянемо окремі частини рисунка.

1. Грунт, трава - це основа, те, на чому стоять усі споруди. Робимо візуальну прив'язку до джерел міжнародного права. Джерелами міжнародного права $є$ договірні та звичаєві норми, які формують основу міжнародного права та розповсюджуються на всі міжнародні відносини.

2. Принципи міжнародного права - це основні засади та правові норми, що мають найвищу юридичну силу та здатні впливати на всі взаємовідносини в галузі міжнародного права. Такі принципи мають імперативний характер (jus cogens) і є обов' язковими до виконання для всіх учасників. Відповідно до ст. 53 Віденської конвенції про право міжнародних договорів (1969) відхилення від норм јus cogens - неприпустиме. Саме тому принципи на рисунку зображені у вигляді фундаменту - основної опори, як уособлення того, що закладає початок формування держав, націй і відносин між ними [1].

3. Будинки - це візуальна прив'язка до території. Будинок як капітальна споруда уособлює собою надійність, має чіткі межі та виконує функцію житла для людей. Отже, державні території ми зображаємо у вигляді будинку. У міжнародному праві під територіями розуміють природні простори земної кулі, повітряний простір в атмосфері Землі, космічний простір, небесні тіла, а також штучні об'єкти та споруди.

4. Відповідно до Віденської конвенції про правонаступництво держав щодо договорів «правонаступництво держав» означає заміну однієі держави іншою в несенні відповідальності за міжнародні відносини якої-небудь території. Тобто нова держава забирає у старої усі майнові та немайнові зобов'язання. Використовуємо для візуалізації мнемоніку: держави - це будинки. Отже, правонаступництво у даному випадку - це переселення зі старого будинку до нового із перенесенням речей та майна.

5. Суб'єкти міжнародного права можна візуалізувати як квіти, комаху-сонечко, жабу. Відповідно пояснюємо, що існують різні види суб'єктів міжнародного права: держави, народи та нації, що борються за незалежність, міжнародні організації та інші похідні суб'єкти міжнародного права.

6. Для того, щоб налагодити відносини між державами, діє право зовнішніх зносин. Дипломатичні та консульські служби ніби двері, що поєднують декілька держав і допомагають налагодити співпрацю в економічній, політичній, культурній та інших сферах. Саме тому відображаємо дипломатичні та консульські зносини у вигляді дверей.

7. Коло питань, які належать до відання міжнародного права, називають юрисдикцією. Юрисдикція охоплює всі сфери міжнародних відносин. Тому візуалізуємо ії̈ як дим, який ніби огортає все навколо.

8. Договірне право - це основа взаємин між державами. Так формуються взаємні обов'язки, права, імунітети та гарантії. У ст. 26 Віденської конвенції про право міжнародних договорів (1969) зазначено: «Pacta sunt servanda - кожен чинний договір $€$ обов'язковим для його учасників і повинен добросовісно виконуватися» [1].

9. Міжнародне морське право - це галузь міжнародного права, принципи та норми якої визначають статус морських просторів, зокрема морського дна та ресурсів, а також порядок користування ними [3]. Візуалізуємо прив'язку за допомогою зображення озера.

10. Міжнародне повітряне право позначено хмаринкою, що відображає сукупність принципів і норм, які регулюють відносини між суб' єктами міжнародного права щодо використання повітряного простору цивільною авіацією. Найсуттєвіші норми щодо регламентації міжнародних повітряних сполучень містить Чиказька конвенція про міжнародну цивільну авіацію від 7 грудня 1944 року з доповненнями від 1962, 1972, 1973 років [7].

11. Продовжуючи будувати асоціативні зв'язки, використовуємо Сонце як прив'язку до міжнародного космічного права. Оскільки Сонце - це небесне тіло, то пояснюємо, що міжнародне космічне право - це галузь міжнародного публічного права, що містить у собі спеціальні принципи та норми, які встановлюють правовий режим космічного простору, небесних тіл, а також регулюють права та обов'язки учасників космічної діяльності [2].

12. Міжнародне гуманітарне право складається 3 принципів і норм, що обороняють цивільне населення під час ведення військових дій, захищають жертв війни, а також обмежують засоби та методи ведення війти. Недаремно проводимо асоціативний зв'язок і позначаємо міжнародне гуманітарне право у вигляді даху будинку. Таким чином візуально убезпечуємо державну територію.

13. Охорона навколишнього середовища від шкідливих впливів і раціональне ресурсовикористання на міжнародному рівні визначається як міжнародне екологічне право. Застосовуємо дерево для фіксації сталого асоціативного зв'язку.

Використовувати метод мнемоніки на заняттях із міжнародного права доцільно не лише на вступних лекціях. Для прикладу, наведемо асоціативний рисунок до лекційного заняття 3 теми «Територія, населення та міжнародне право» (див. рис. 2).

Для створення асоціативної прив'язки було використано старовинний парусний корабель. Такий візуальний образ допоможе студентам швидше засвоїти матеріал лекції та зацікавить їх до подальшого вивчення міжнародного права. Отже, корабель уособлює міжнародні території. Він великий, надійний 


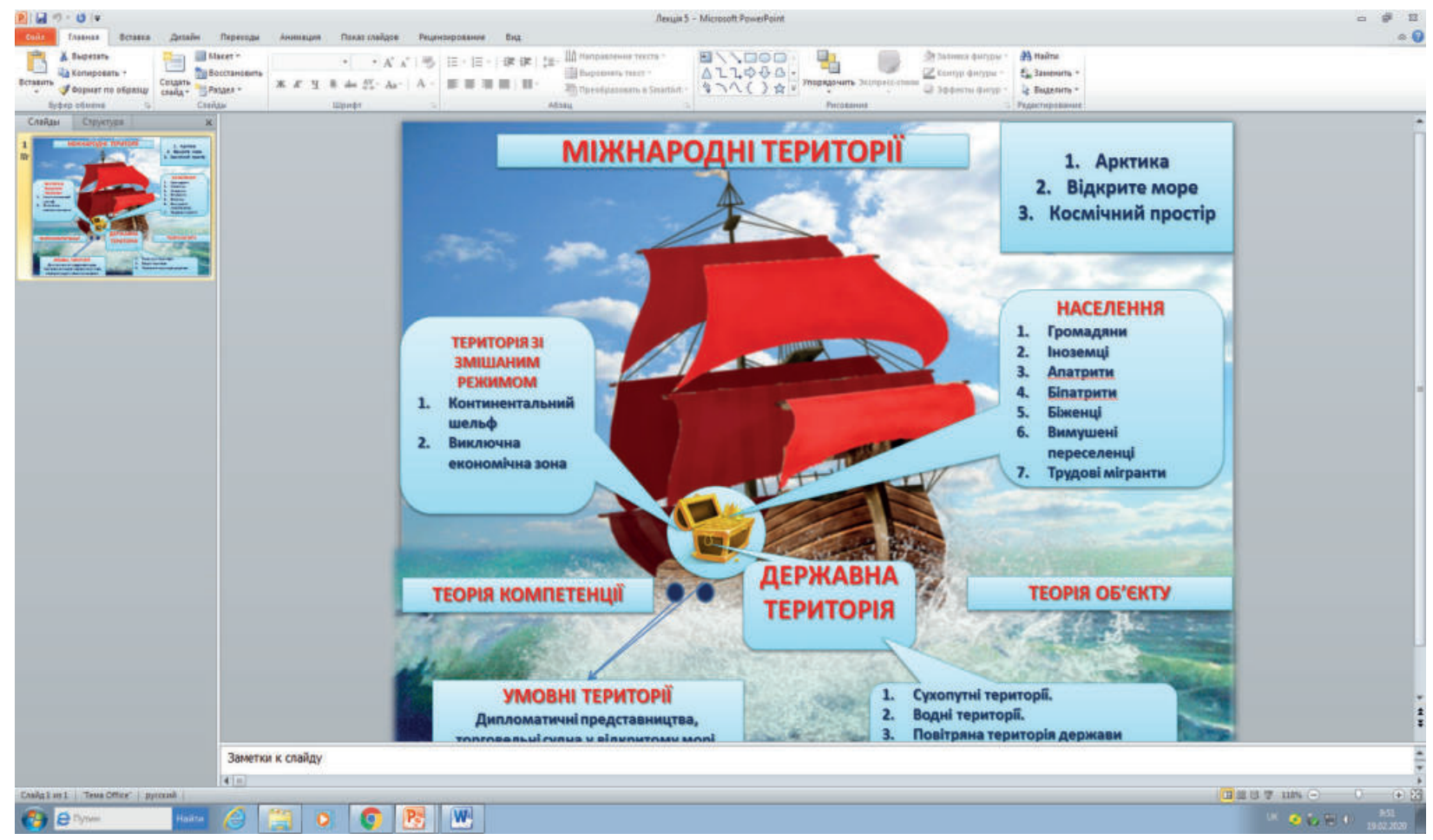

Рис. 2. Скрайбінг-презентаиія до лекиї «Територія, населення та міжнародне право» з елементами мнемоніки

і ним можуть користуватись за призначенням усі, хто забажає. Скриня на борту корабля - це державні території. Повідомляємо в ході лекції, що таких скринь на борту є багато, кожна з них має своє внутрішнє наповнення та відіграє певну роль. Всередині скрині - населення країни. Для прикладу беремо цукерки. Скриня заповнена різними цукерками: із чорного та молочного шоколаду, карамельок тощо. Створюємо асоціативний зв'язок із видами населення: громадяни, апатриди, біпатриди, іноземці, біженці тощо. Кожна скриня має обгортку, яка відділяє скриню від корабля. Це території зі змішаним режимом, правовий режим яких визначається одночасно як нормами міжнародного права, так і нормами національного права прибережної держави [4]. Застосувавши асоціативні лінії, розглянемо кожен вид міжнародних територій, не забуваючи використовувати мнемоніку впродовж усієї лекції.

Висновок. Отже, технології презентацій набувають наразі ще більшої актуальності в умовах глобалізації не лише економіки та освіти, а й захворювань. Адже зацікавити студентів звичним читанням підручників під час дистанційного навчання, налаштувати їх на розвиток фахової компетентності та вмотивувати до подальшого вивчення дисципліни виявилося завданням не з легких. Методи, що спрощують інформацію, подають її у звичному для сприйняття вигляді та полегшують запам'ятовування в сучасних реаліях. Це необхідна складова успішного та якісного навчання.

Таким чином, використання методу мнемоніки відіграє важливе значення для підготовки фахівців із міжнародного права. Мотивація студентів і формування в них навичок практичного використання набутих під час дистанційної освіти теоретичних знань суттєво впливають на якість підготовки фахівців із міжнародного права, а це водночас забезпечує їхню готовність до використання проєктивних технологій у професійній діяльності.

\section{СПИСОК ВИКОРИСТАНОЇ ЛІТЕРАТУРИ}

1. Віденська конвенція про право міжнародних договорів 1969 p. URL: https://zakon.rada.gov.ua/laws/ show/995_118 (дата звернення: 04.05.2020).

2. Договір про принципи діяльності держав по дослідженню і використанню космічного простору, включаючи Місяць та інші небесні тіла від 27.01.1967. URL: https://zakon.rada.gov.ua/laws/show/995_480 (дата звернення: 07.05.2020).

3. Конвенція Організації Об'єднаних Націй 3 морського права ООН від 10.12.1982. URL: https:// zakon.rada. gov.ua/laws/show/995_057 (дата звернення: 05.05.2020).

4. Пронюк Н. В. Сучасне міжнародне право : навч. посіб. Вид 2-ге, змін. та допов. Київ : КНТ, 2010. 344 c.

5. Скрайбінг - новітня техніка презентації. URL: https:/osvita.ua/ school/scribing/51803/ (дата звернення: 07.05.2020).

6. Теліпко В. Е., Овчаренко А. С. Міжнародне публічне право : навч. посіб. / за заг. ред. В. Е. Теліпко. Київ : Центр навчальної літератури, 2010. 608 с.

7. Чиказька конвенція про міжнародну цивільну авіацію від 07 грудня 1944. URL: https://zakon. rada.gov.ua/laws/show/995_038 (дата звернення: 06.05.2020).

Дата надходження до редакиіi:: 10.05.2020 р. 